\title{
Augmentative and alternative communication in children with Down's syndrome: a systematic review
}

\author{
Renata Thaís de Almeida Barbosa ${ }^{1 *}$, Acary Souza Bulle de Oliveira², Jennifer Yohanna Ferreira de Lima Antão ${ }^{1}$, \\ Tânia Brusque Crocetta ${ }^{1}$, Regiani Guarnieri ${ }^{1}$, Thaiany Pedrozo Campos Antunes ${ }^{1}$, Claudia Arab ${ }^{3}$, Thaís Massetti ${ }^{4}$, \\ Italla Maria Pinheiro Bezerra ${ }^{5}$, Carlos Bandeira de Mello Monteiro ${ }^{1,4,6}$ and Luiz Carlos de Abreu ${ }^{1,7}$
}

\begin{abstract}
Background: The use of technology to assist in the communication, socialization, language, and motor skills of children with Down's syndrome (DS) is required. The aim of this study was to analyse research findings regarding the different instruments of 'augmentative and alternative communication' used in children with Down's syndrome.

Methods: This is a systematic review of published articles available on PubMed, Web of Science, Psyclnfo, and BVS using the following descriptors: assistive technology AND syndrome, assistive technology AND down syndrome, down syndrome AND augmentative and alternative communication. Studies published in English were selected if they met the following inclusion criteria: (1) study of children with a diagnosis of DS, and (2) assistive technology and/or augmentative and alternative communication analysis in this population.

Results: A total of 1087 articles were identified. Thirteen articles met the inclusion criteria. The instruments most used by the studies were speech-generating devices (SGDs) and the Picture Exchange Communication System (PECS).

Conclusion: Twelve instruments that provided significant aid to the process of communication and socialization of children with DS were identified. These instruments increase the interaction between individuals among this population and their peers, contributing to their quality of life and self-esteem.
\end{abstract}

Keywords: Down's syndrome, Children, Assistive technology, Augmentative and alternative communication

\section{Background}

According to the World Health Organization (WHO), one in every 1100 children born worldwide harbours a chromosome 21 genetic abnormality. In the United States, 250,000 families are affected by Down's syndrome (DS) [1] with a prevalence of one per 691 live births [2].

DS is a disorder caused by trisomy of human chromosome 21 (Hsa21) and presents various anomalies of the respiratory, cardiovascular, sensory (organs), gastrointestinal, haematological, immune, endocrine, musculoskeletal, renal, and genitourinary systems [3]. Furthermore, individuals with DS may have changes in body anatomy,

\footnotetext{
*Correspondence: profrenatathais@gmail.com

${ }^{1}$ Laboratório de Delineamento de Estudos e Escrita Científica, Departamento de Saúde da Coletividade, Faculdade de Medicina do ABC (FMABC), Rua Fagundes Varela, 121. Vila Príncipe de Gales, 09060510 Santo André, SP, Brasi Full list of author information is available at the end of the article
}

such as different facial features with a rounded and flat face, an epicanthic fold, an oblique palpebral cleft, dysmotic ears, a flat and flattened nose, a short and wide neck, a small mouth with hypotonic tongue with tongue protrusion, brachycephaly, short stature, hands that may present clinodactyly or syndactyly, a single palmar fold, and small feet $[3,4]$. With regard to development and cognitive aspects, this population can present difficulty in learning [5]. For example, the majority of children with DS exhibit a moderate degree of intellectual disability $[4,6]$, a low Intelligence Quotient (IQ), and low memory [7].

Considering the cognitive aspects, growth, and learning process associated with psychological, cultural, and environmental factors is especially important for children with DS because they need to be integrated into society and have autonomy and independence in their activities [8].

(c) The Author(s). 2018 Open Access This article is distributed under the terms of the Creative Commons Attribution 4.0 International License (http://creativecommons.org/licenses/by/4.0/), which permits unrestricted use, distribution, and 
Given that DS is a common chromosomal alteration in humans and one of the leading causes of intellectual disability in the world population, it is extremely important to use tools that help in the development of communication to provide better socialization [9].

One possibility of supporting the communication process is through tasks that are fun and provide cognitive and motor stimuli, especially for those with communication deficits who often need to use complementary, additional or amplified communication systems to establish an interaction process [10]. Thus, one technology specifically designed to help individuals without functional speech or writing or with a gap between their communicative need and their actual ability to communicate (speak and/or write) is 'augmentative and alternative communication' (AAC) [11].

AAC includes aided communication modes that require additional materials or devices and is subdivided into high and low-technology AAC. Low-technology systems or devices encompass communication books or boards (non-powered), written words on paper, photographs, line drawings and pictograms. High-technology systems include voice output communication aids (VOCAs), which are known as 'speech-generating devices' in North America, and software on personal computers or laptops used as communication aid (providing recorded or synthesized voice or written output). Moreover, the concept includes technology that provides access to personal computers or laptops, enabling their use as communication aids [12].

According to Foreman and Crews [8], children with DS often present difficulties in language and communication as well as visual and perceptual areas, thereby suggesting that they may potentially benefit from using $\mathrm{AAC}$ systems to improve language development, communication, and consequently the socialization process. In this context, AAC is a key area of research aimed at studying and developing mechanisms, tools, and methodologies to complement, supplement, or increase the potential for communication [10] and has been widely used with different disorders.

Some studies highlight the importance of the relevance of the intervention for the AAC. For example, Soto and Clarke [13] demonstrated the positive effects of the conversation-based intervention for improving the expressive vocabulary and grammatical skills of children with severe motor speech disorders and expressive language delay who use augmentative and alternative communication. Moreover, their study discusses clinical and theoretical implications of conversation-based interventions and identifies future research needs in the area. Finke et al. [14] studied school-age children with autism spectrum disorder (ASD) and identified benefits associated with the use of AAC with high-technology devices for multi-symbol messages. In a review with adults with post-stroke aphasia, Russo et al. [15] described a compensatory strategy to enhance communicative skills with AAC technology.

With regard to DS, several systemic reviews have been reported on observed reading skills [16], language and verbal short-term memory skills [17], and cognitive and behavioural functioning across the lifespan [18] as well as studies on reading comprehension in developmental disorders of language and communication [19]. However, no review studies have been found that observed the instruments used for AAC for DS.

Therefore, the aim of this study is to investigate the results presented in previous studies (i.e., clinical trials, case-control, cross-sectional, case reports, and case series) on AAC use in children with DS observing the different instruments used for communication. The presentation of existing knowledge about technological modernity and this new communication tool in DS can help in the organization of treatment programmes and benefits aimed at improving the communication and independence of this population.

\section{Methods}

\section{Search strategy}

This review was based on a systematic search conducted in August 2017 of published articles available on PubMed (http://www.ncbi.nlm.nih.gov/pubmed), Web of Science (https://webofknowledge.com/), BVS - Virtual Health Library (http://bvsalud.org/), and PsycInfo (http:// www.apa.org/pubs/databases/psycinfo/index.aspx) using keywords obtained from the Health Sciences Descriptors (DeCS) of the Virtual Health Library. The searches were conducted thrice on each database (See Table 1). We used the descriptor 'syndrome' in all searches to ensure that all potential articles were obtained. The review was performed according to the Preferred Reporting Items for Systematic Reviews and Meta-Analyses (PRISMA) guidelines [20]. The use of checklists, e.g., PRISMA, improves the reporting quality of systematic reviews and provides substantial transparency in the article selection process $[21,22]$.

Finally, reference lists of retrieved studies were handsearched to identify additional relevant studies. Keywords and a combination of keywords were used to search the electronic databases. We organized the search and selection of studies following the Population Intervention Comparison Outcome Study Design (PICOS) strategy. As performed by Massetti et al. [23], Sampaio and Mancini [24], and Massetti et al. [25], we used the search strategy based on their composition according to the PICOS method to locate and compare different works (Fig. 1). In this model, the search strategy is based on the topics of population (P), intervention (I), control 
Table 1 Studies searches according to database, terms and quantity of returned studies

\begin{tabular}{|c|c|c|}
\hline Database & Search terms & $\begin{array}{l}\text { Articles } \\
\text { returned, } \mathrm{n}\end{array}$ \\
\hline $\begin{array}{l}\text { 1st search in } \\
\text { Web of Science }\end{array}$ & $\begin{array}{l}\text { Topic: (assistive technology AND } \\
\text { syndrome) AND (language:("English") } \\
\text { AND type:("article") }\end{array}$ & 45 \\
\hline $\begin{array}{l}\text { 2nd search in } \\
\text { Web of Science }\end{array}$ & $\begin{array}{l}\text { Topic: (assistive technology AND down } \\
\text { syndrome) AND (language:("English") } \\
\text { AND type:("article") }\end{array}$ & 4 \\
\hline $\begin{array}{l}\text { 3rd search in } \\
\text { Web of Science }\end{array}$ & $\begin{array}{l}\text { Topic: (down syndrome AND } \\
\text { augmentative and alternative } \\
\text { communication) AND (language:("English") } \\
\text { AND type:("article") }\end{array}$ & 17 \\
\hline $\begin{array}{l}\text { 1st search in } \\
\text { PubMed }\end{array}$ & $\begin{array}{l}\text { (Search details): (assistive technology } \\
\text { [All Fields] AND syndrome [All Fields]) }\end{array}$ & 218 \\
\hline $\begin{array}{l}\text { 2nd search in } \\
\text { PubMed }\end{array}$ & $\begin{array}{l}\text { (Search details): (assistive technology [All } \\
\text { Fields] AND down syndrome [All Fields]) }\end{array}$ & 25 \\
\hline $\begin{array}{l}\text { 3rd search in } \\
\text { PubMed }\end{array}$ & $\begin{array}{l}\text { (Search details): (down syndrome } \\
\text { [All Fields] AND augmentative and } \\
\text { alternative communication [All Fields]) }\end{array}$ & 20 \\
\hline $\begin{array}{l}\text { 1st search in } \\
\text { Psyclnfo }\end{array}$ & $\begin{array}{l}\text { Any Field: augmentative AND Any Field: } \\
\text { alternative communication AND Any } \\
\text { Field: "down syndrome" }\end{array}$ & 0 \\
\hline $\begin{array}{l}\text { 2nd search in } \\
\text { Psyclnfo }\end{array}$ & $\begin{array}{l}\text { Any Field: assistive technology AND } \\
\text { Any Field: "down syndrome" }\end{array}$ & 0 \\
\hline $\begin{array}{l}\text { 3rd search in } \\
\text { Psyclnfo }\end{array}$ & $\begin{array}{l}\text { Any Field: assistive technology } \\
\text { AND Any Field: syndrome }\end{array}$ & 56 \\
\hline $\begin{array}{l}\text { 1st search in } \\
\text { BVS }\end{array}$ & $\begin{array}{l}\text { All fields: assistive technology } \\
\text { AND syndrome }\end{array}$ & 655 \\
\hline $\begin{array}{l}\text { 2nd search in } \\
\text { BVS }\end{array}$ & $\begin{array}{l}\text { All fields: assistive technology } \\
\text { AND down syndrome }\end{array}$ & 14 \\
\hline $\begin{array}{l}\text { 3rd search in } \\
\text { BVS }\end{array}$ & $\begin{array}{l}\text { All fields: down syndrome AND } \\
\text { augmentative AND alternative } \\
\text { communication }\end{array}$ & 33 \\
\hline
\end{tabular}

group $(\mathrm{C})$, outcome $(\mathrm{O})$, and study design $(\mathrm{S})$ as well as several searches in the cited databases.

\section{Selection process}

We used three steps to select the articles. The first step involved searching for the articles in the databases and reading the titles and abstracts. The second step involved the exclusion of works using the title or abstract and inclusion criteria analysis. The third and final step was to analyse the full text of the eligible works [26, 27]. After the removal of duplicates, two authors evaluated the titles, abstracts, and inclusion criteria independently.

\section{Inclusion criteria}

Studies published in English were eligible if they met the following criteria: (1) study of children with a diagnosis of DS, and (2) assistive technology and/or AAC analysis in this population. There were no restrictions regarding sample size. To determine the age range limit, we used the chronological limits of the child defined by the Brazilian Child and Adolescent Statute (ECA). This statute defines a typical child as a citizen under 12 years of age [28] and those between 12 and 18 years of age as adolescents. These guidelines also encompass the range limit proposed by the WHO of 9 years, 11 months, and 29 days [29].

In our study, we did not restrict the time of publication or the type of study design; all publications found, except for reviews, were included.

\section{Exclusion criteria}

Articles were excluded if they (1) were not databased (e.g., books, theoretical papers or secondary reviews, reviews, and meta-analyses), (2) were not published in English, or (3) used populations not explicitly identified with a diagnosis of DS.

\section{Data extraction and study quality}

Data from the included studies were extracted using Microsoft Excel 2010. The form included fields to be completed by a reviewer in the following order: (1) study identification (main author's name, year, and country), (2) study method (type of study, blinding, and secret allocation), (3) target population aspects (age and sex), (4) aspects of the intervention performed (sample size, presence of supervision, frequency, session length, and follow-up), (5) presence of follow-up, (6) loss to followup, (7) studied outcomes, and (8) presented results (see Tables 2 and 3).

After performing the initial literature searches, each study title and abstract was screened for eligibility by RTAB and JYFLA. The full text of all potentially relevant studies was subsequently retrieved and further examined for eligibility. To increase confidence in article selection, all potentially relevant articles were reviewed independently by two researchers (RTAB and JYFLA) [24]. In the case of disagreement between them, a third researcher (TBC) was approached for a solution.

The authors of the study had the following functions: RTAB structured the script and directed the work; RTAB and JYFLA collected the studies and organized the data; TM, TBC and CA structured the method and study analysis; ASBO, CBMM and LCA structured the introduction, discussion, and conclusion; CA and TPCA adapted the work to the English language; RG, TPCA and IMPB helped in the construction of the discussion; and LCA reviewed and generally organized the manuscript. It is important to emphasize that the list of articles from the references was analysed as described by Arab et al. [30]; however, this method did not change the results of the initial search.

\section{Analyses}

The study evaluation was performed using the PEDro scale (see Table 3), one of the most used scales in the 


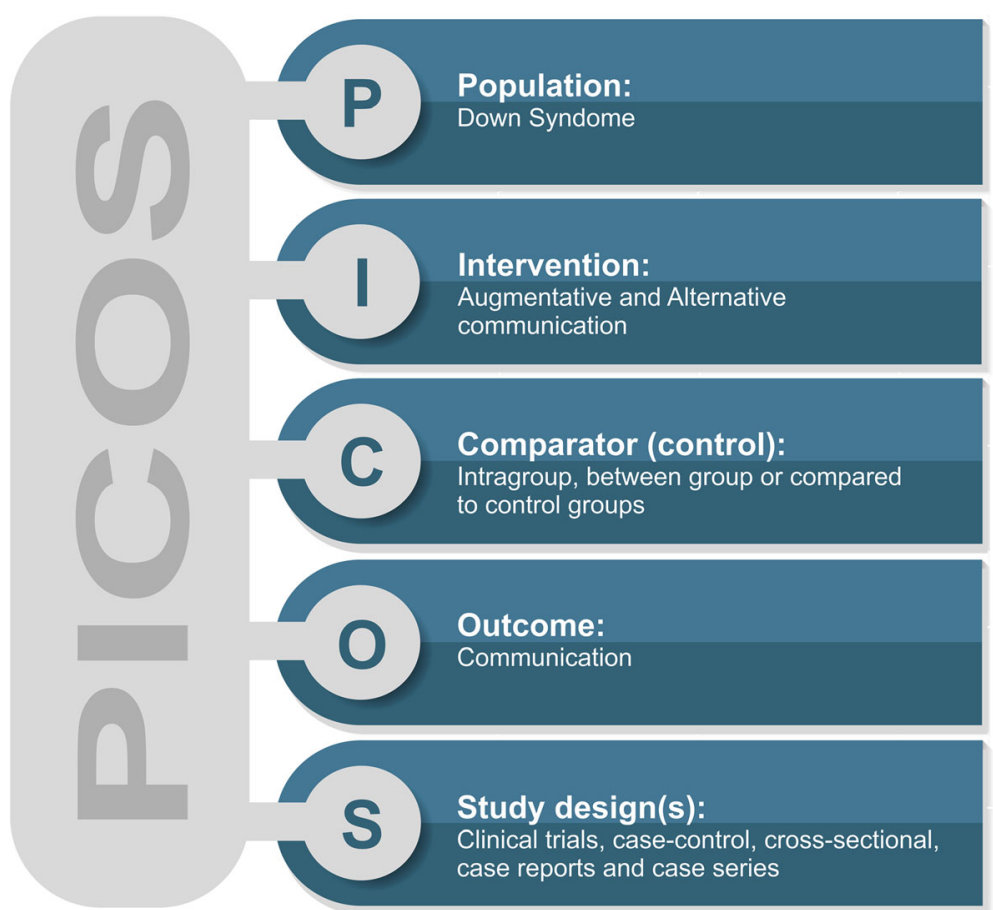

Fig. 1 Population Intervention Comparison Outcome Study Design (PICOS) strategy

rehabilitation area [31]. This scale was developed as a part of the Physiotherapy Evidence Database to evaluate experimental studies and has a total score of 10 points, including internal validity of evaluation criteria and presentation of statistical analysis [31]. These criteria are contained in the Delphi list developed by Verhagen et al. [32] and are used to evaluate items in systematic reviews. According to Maher et al. [33], PEDro score efficiency assesses the reliability of the total score based on judgements of acceptable consensus. We followed the methodological quality proposed by Snider et al. [34] and Massetti et al. [26], which ranked the study-level evidence using the following scoring scale: 'Excellent' 9-10, 'Good' 6-8, 'Fair' 4-5, and 'Poor' $<4$.

\section{Results}

PubMed, Web of Science, PsycInfo, and BVS database searches resulted in 1087 articles. After filtering articles by reading titles and abstracts, we selected 17 articles for full-text reading. Of these, 13 articles fulfilled the inclusion criteria for this review (Fig. 2) (see Additional file 1, Additional file 2, Additional file 3, and Additional file 4).

\section{Discussion}

The studies used predominantly visual and auditory instruments for communication to provide socialization. We identified twelve instruments used for communication for children with DS (see Table 4) as described below.

\section{Primary and secondary outcomes}

Given that individuals with Down's syndrome (DS) have cognitive, language, and socialization deficits and motor delay, it is important to present augmentative and alternative communication (AAC) instruments to this population. The instruments found will be displayed in topics according to the frequency in which they appeared in the results sample. Thus, the instruments will be presented considering the number of studies identified, the number and age of participants with DS and the main improvements brought by the instrument used in DS.

\section{Speech-generating devices (SGDs)}

Four studies [35-38] used speech-generating devices (SGDs). These studies included a total of 29 children with DS from 3 to 12 years of age and reported similar results. The efficacy of these instruments in DS was demonstrated by improved communication due to speech improvement, cognition, and socializing. However, the findings from the study by Sigafoos et al. [39] demonstrated that intervention with these instruments only was not sufficient to promote the process of social interaction.

It is interesting to note that SGDs are more frequently used in other populations with developmental disabilities, such as severe apraxia [40] and ASD [41-44], providing communication development through progress in the variables of language, reduction of inappropriate vocalizations, improved social communication, and disruptive behaviour. 


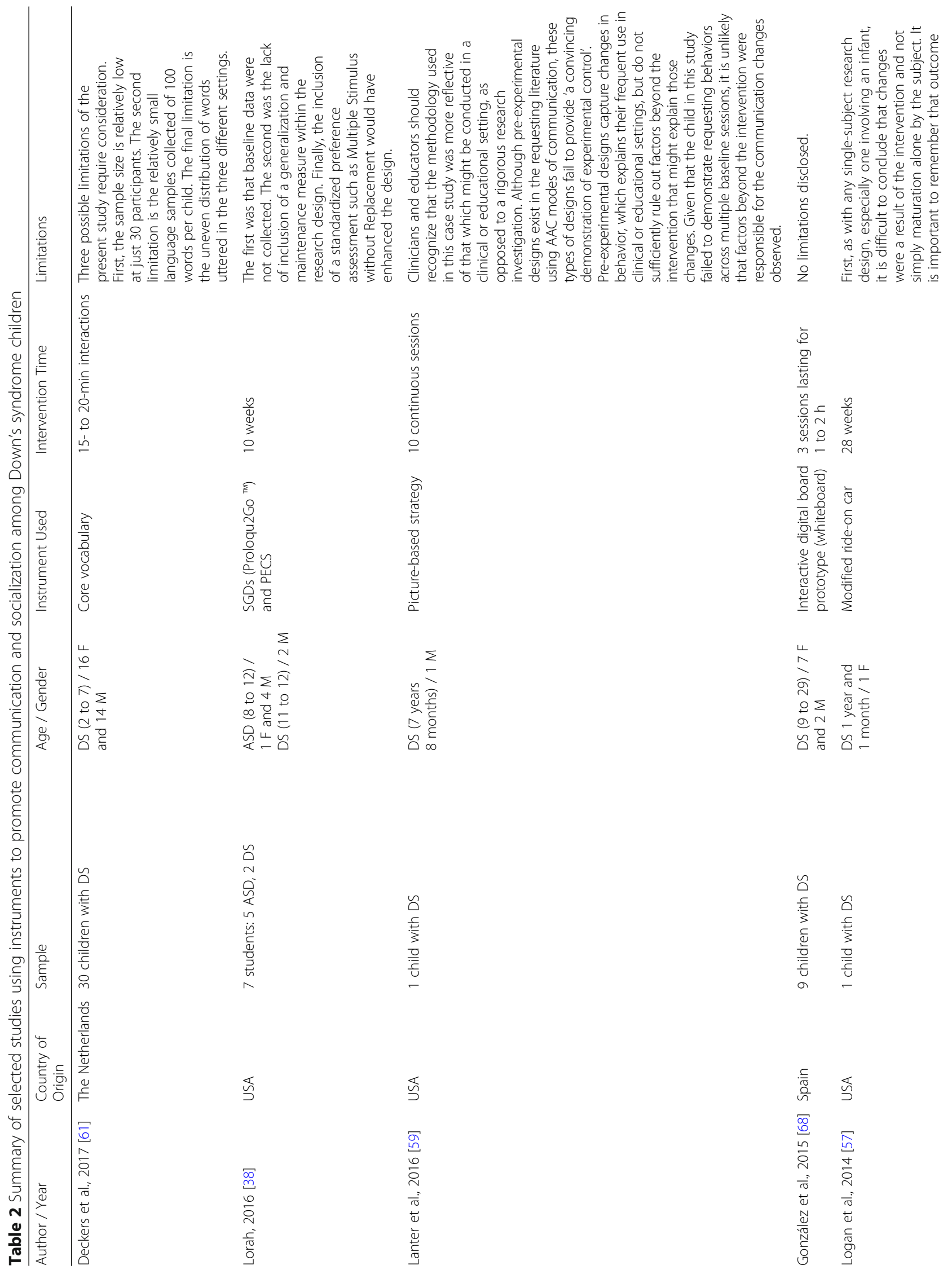




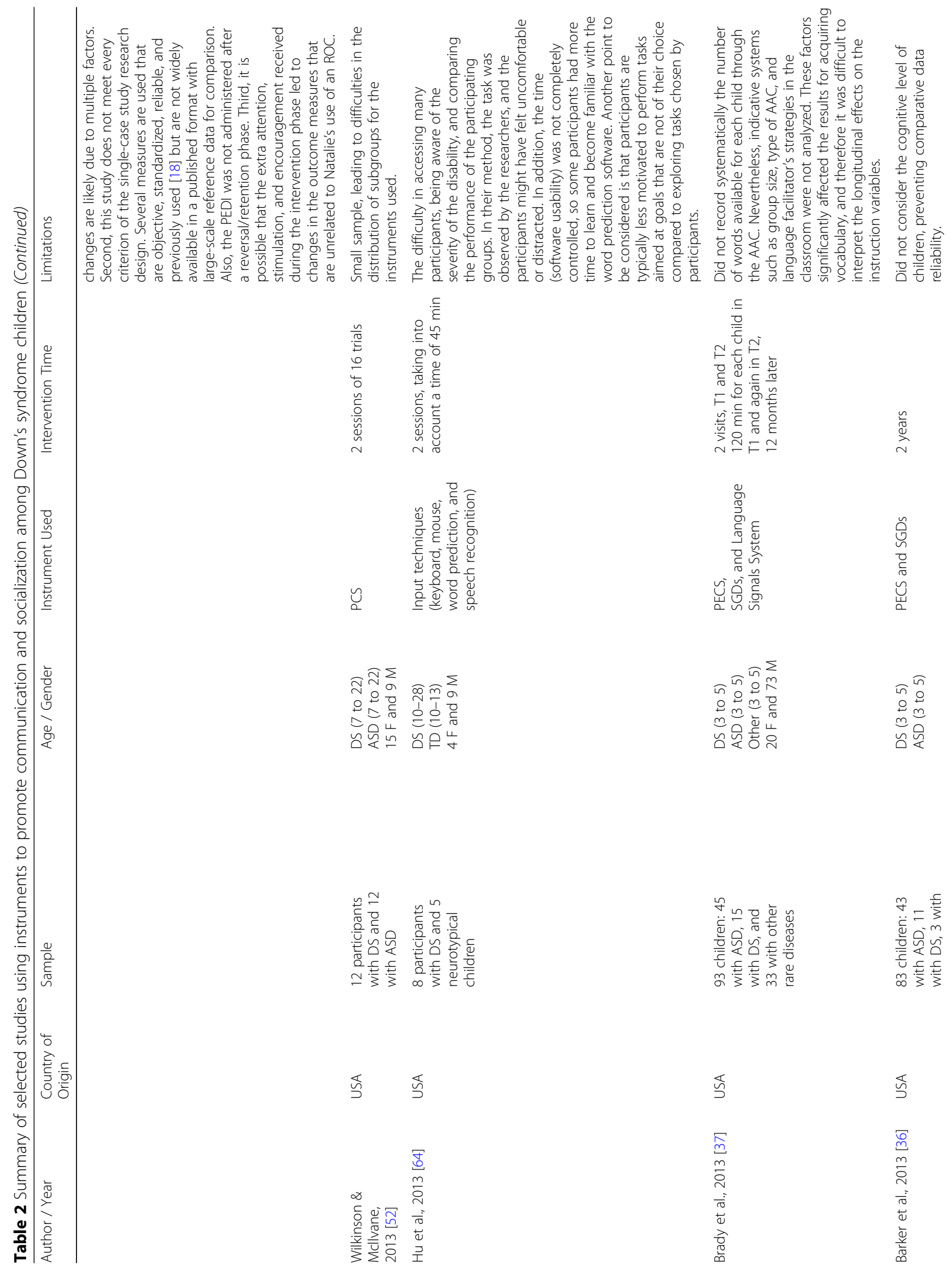




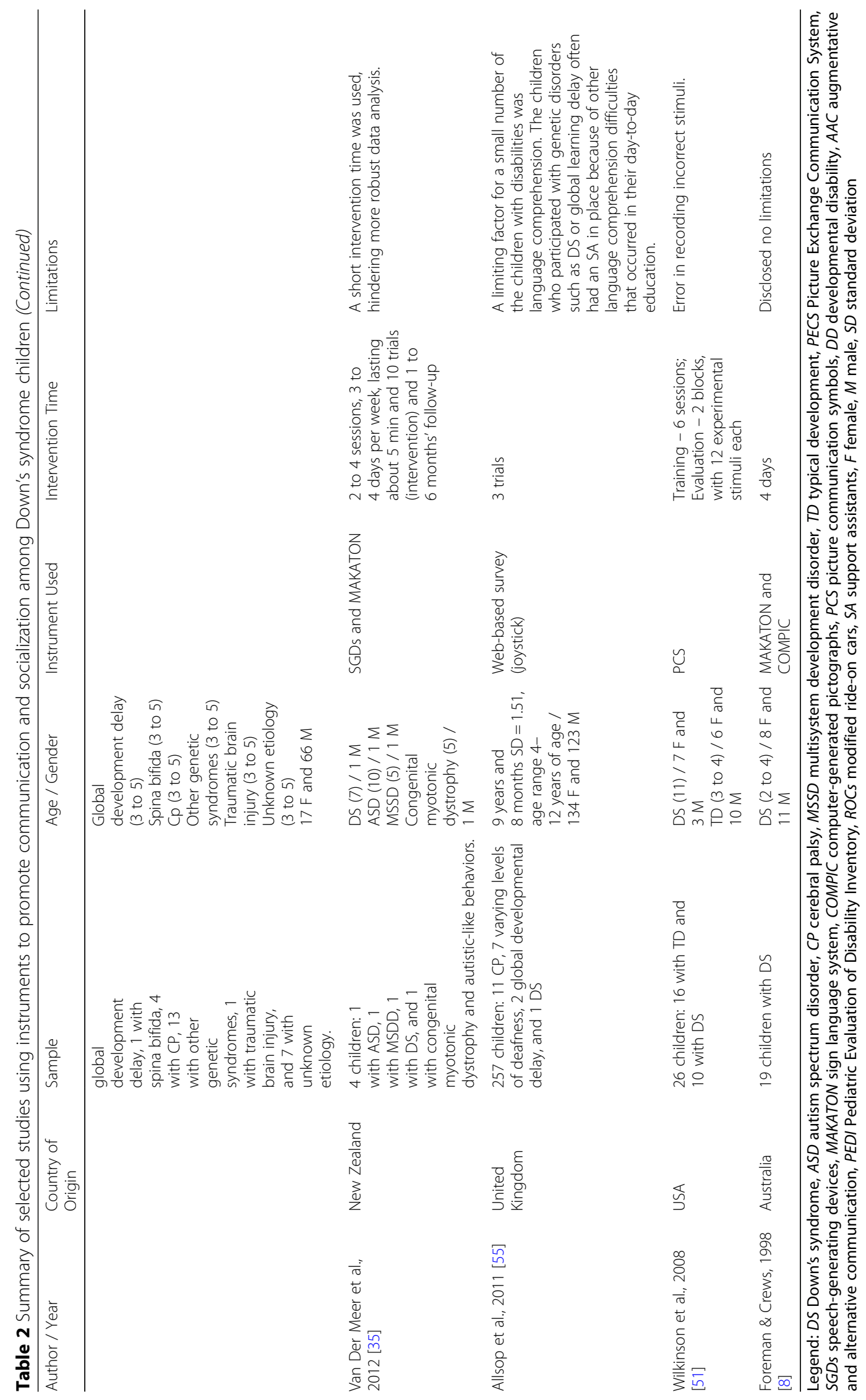




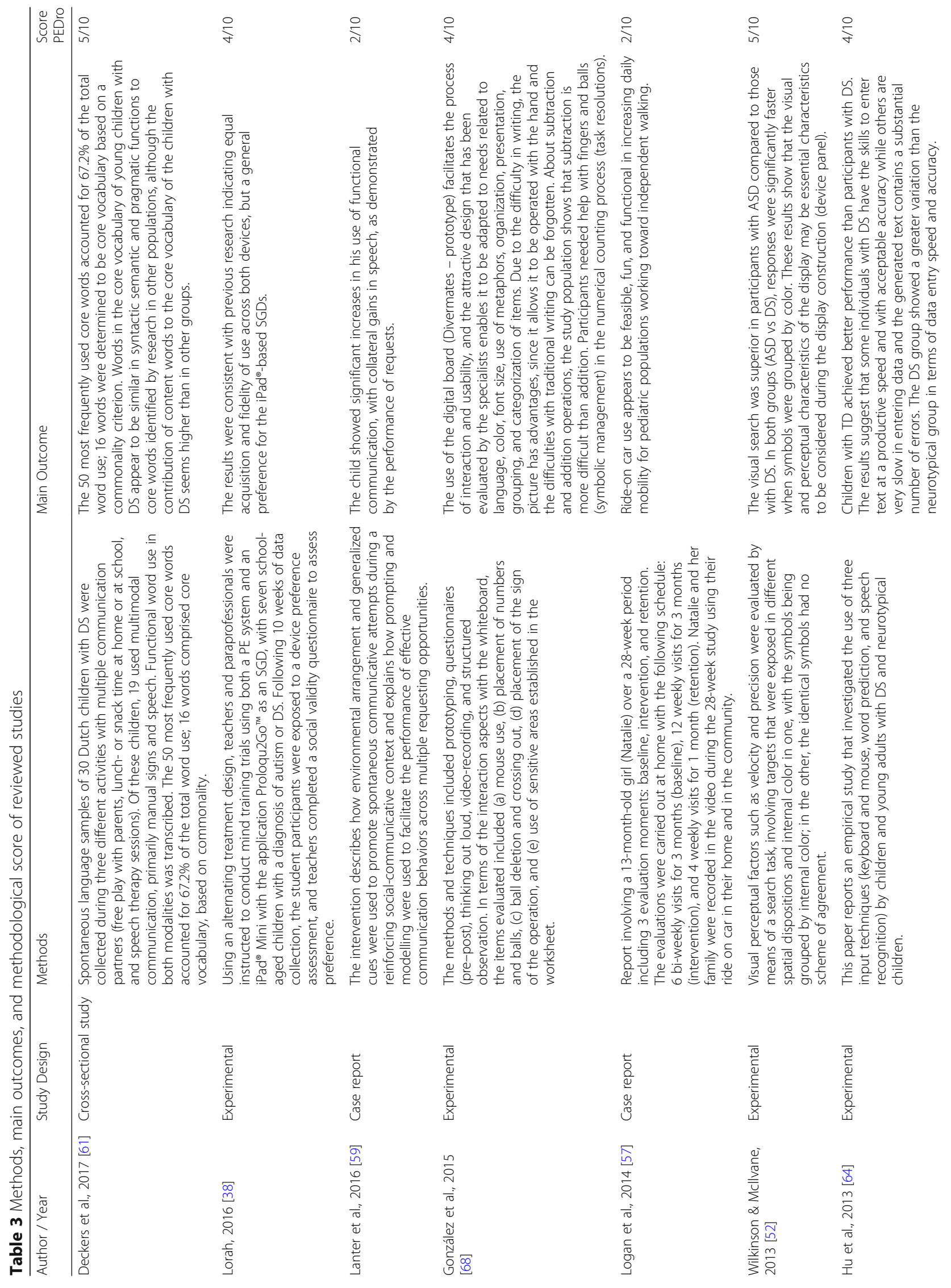




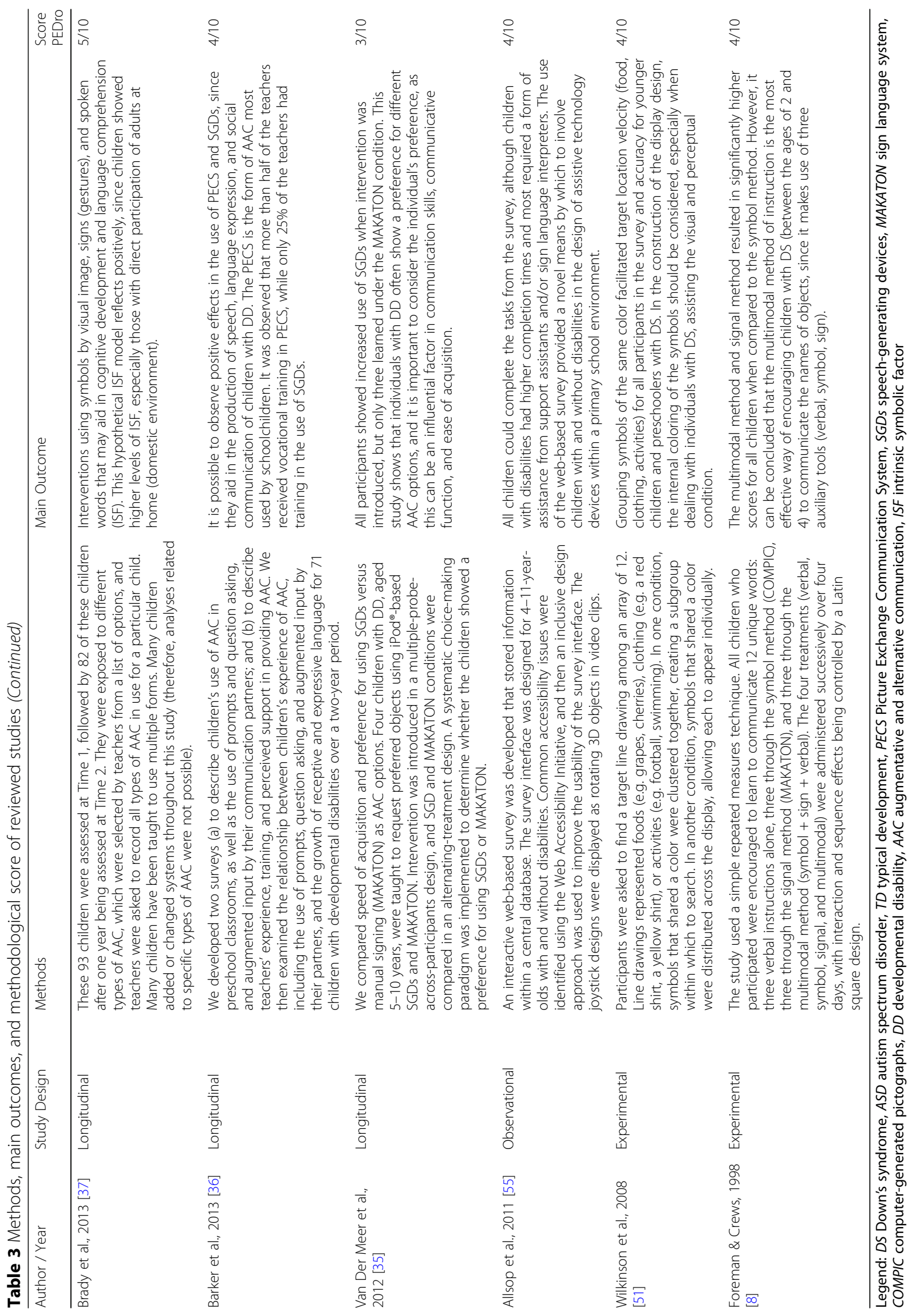




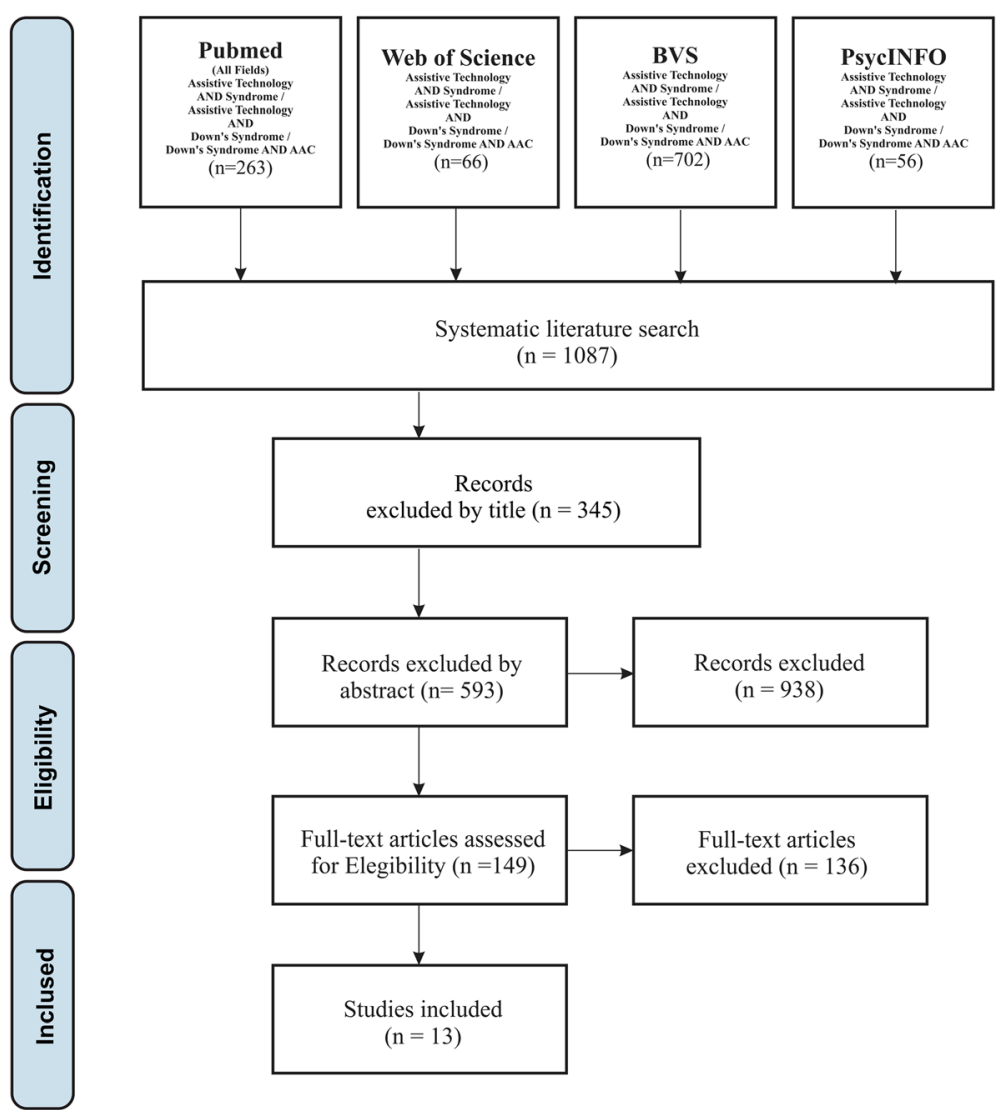

Fig. 2 Flow chart of search strategy and selection of the articles. Initialism: AAC: augmentative and alternative communication. Overview of the literature review process. Adapted from Moher et al. (2009)

SGDs could probably be used more in DS; therefore, teachers should be trained and specialized. According to Barker et al. [36], the Picture Exchange Communication System (PECS) is the most commonly used AAC in DS, and teachers have a higher level of training. In contrast, only $25 \%$ of teachers have training in the use of SGDs.

\section{Picture Exchange Communication System (PECS)}

Three studies [36-38] used Picture Exchange Communication System (PECS). These studies included a total of 28 children with DS from 3 to 12 years old. These studies obtained satisfactory results after a follow-up study, and similar results regarding improvements in language skills and social communication were reported.

Converging these findings, the PECS was successfully used to increase interaction among individuals with DS and their peers with a consequent influence on their quality of life [45].

In studies with individuals diagnosed with autism spectrum disorder, the results using the PECS are similar in terms of improving communication and the socialization process [46]. In addition, among preschoolers diagnosed with pervasive developmental disorder not otherwise specified, improvements in spoken communication and an increased number of different words after intervention with the PECS were identified in a six-month follow-up [47].

\section{Sign language system (MAKATON)}

Two studies [8, 35] used a sign language system (MAKATON) with a total of 20 children with DS from 2 to 7 years old. Improvements in language development were noted.

This instrument is being investigated in children as well as adults [48]. Adults with learning disabilities aged 18 to 44 years interacted with researchers through MAKATON signs, assisting in systemic family therapy. Furthermore, the instrument is important in educational environments, i.e., students with difficulties in learning and socialization [49]. For typical individuals and individuals with developmental disabilities, MAKATON can aid in the communication and learning processes, providing educational value and fun [50].

\section{PCS: Picture communication symbols}

Two studies [51, 52] used Picture Communication Symbols (PCS) with a total of 22 people with DS ranging from 7 to 22 years old. This set of symbols is a communication tool 
Table 4 Objectives and characteristics of the instruments used in included studies

\begin{tabular}{|c|c|c|c|}
\hline Instrument & Instrument Objective & Instrument Features & $\begin{array}{l}\text { Number of } \\
\text { Studies (Instrument) }\end{array}$ \\
\hline SGDs & $\begin{array}{l}\text { Improvement of speech } \\
\text { (improvement of communication) }\end{array}$ & $\begin{array}{l}\text { SGDs, also known as voice and output } \\
\text { communication aids }\end{array}$ & $\begin{array}{l}\text { Lorah, } 2016[38] \\
\text { Barker et al., } 2013 \text { [36] } \\
\text { Brady et al., } 2013 \text { [37] } \\
\text { Van Der Meer et al., } \\
2012 \text { [35] }\end{array}$ \\
\hline PECS & $\begin{array}{l}\text { Broadening of language skills and } \\
\text { social communication }\end{array}$ & $\begin{array}{l}\text { Information system through the } \\
\text { exchange of image cards (change the } \\
\text { image for the item itself) - discrimination } \\
\text { of figures, making sentences }\end{array}$ & $\begin{array}{l}\text { Lorah, } 2016[38] \\
\text { Barker et al., } 2013 \text { [36] } \\
\text { Brady et al., } 2013[37]\end{array}$ \\
\hline MAKATON & $\begin{array}{l}\text { Language and communication } \\
\text { development (signals domain) }\end{array}$ & $\begin{array}{l}\text { Vocabulary with speech, signs, and/or } \\
\text { symbols (interactive vocabulary) }\end{array}$ & $\begin{array}{l}\text { Van Der Meer et al., } \\
2012 \text { [35] } \\
\text { Foreman \& Crews, } \\
1998[8]\end{array}$ \\
\hline PCS & $\begin{array}{l}\text { Assists the cognitive process } \\
\text { (speed and accuracy) through } \\
\text { figures and symbols }\end{array}$ & $\begin{array}{l}\text { A pictorial system consisting of designs } \\
\text { that mean nouns, pronouns, verbs, and } \\
\text { adjectives, or makes use of symbol } \\
\text { arrangements (e.g. clothing, shoes, } \\
\text { goggles and gloves) used in the "grouped" } \\
\text { and "distributed" arrangement with a search } \\
\text { focus visual. }\end{array}$ & $\begin{array}{l}\text { Wilkinson \& } \\
\text { Mcllvane, } 2013 \text { [52] } \\
\text { Wilkinson et al., 2008 }\end{array}$ \\
\hline Core vocabulary & $\begin{array}{l}\text { Improvement of functional language, } \\
\text { seeking to achieve more effective } \\
\text { communication }\end{array}$ & $\begin{array}{l}\text { Sets of vocabularies described as basic } \\
\text { vocabulary consist of high-frequency words } \\
\text { and represent various parts of speech or } \\
\text { natural text (i.e. mainly function words } \\
\text { such as pronouns, conjunctions, prepositions, } \\
\text { auxiliary verbs, determinants, interjections, } \\
\text { and adverbs). }\end{array}$ & Deckers et al., 2017 [61] \\
\hline Picture-based strategy & $\begin{array}{l}\text { Stimulate spontaneous communicative } \\
\text { attempts }\end{array}$ & $\begin{array}{l}\text { Three-ring communication folder }(\sim 7 " \times 5 " \times 1 \text { ") } \\
\text { that had three removable pages, each with } \\
\text { removable coloured pictures }(\sim 2 \text { " } \times 2 \text { "). The } \\
\text { first page presents snack items and the second } \\
\text { page an immutable series of oral preferred activities } \\
\text { reported to promote generalisation. The third page } \\
\text { shows a phrase strip indicating the target form } \\
(\text { ('I want } \quad \text { '). }\end{array}$ & Lanter et al., 2016 [59] \\
\hline $\begin{array}{l}\text { Interactive } \\
\text { digital board prototype }\end{array}$ & $\begin{array}{l}\text { Facilitate interaction (social skills) and } \\
\text { give personal autonomy }\end{array}$ & $\begin{array}{l}\text { The digital board interface is a subsystem of } \\
\text { the Divermates educational system, which } \\
\text { provides educational tools with an attractive } \\
\text { design. }\end{array}$ & González et al., 2015 [68] \\
\hline $\begin{array}{l}\text { Modified ride- } \\
\text { on car }\end{array}$ & $\begin{array}{l}\text { Improvement of daily mobility, aiding } \\
\text { communication and socialization } \\
\text { processes, plus the fun factor }\end{array}$ & Modified touring car & Logan et al., 2014 [57] \\
\hline $\begin{array}{l}\text { Input } \\
\text { techniques }\end{array}$ & $\begin{array}{l}\text { Vocabulary analysis, performance, } \\
\text { and interaction }\end{array}$ & $\begin{array}{l}\text { Techniques that use computer input devices } \\
\text { (mouse, keyboard, word prediction) for evaluating } \\
\text { the speed and accuracy of data input }\end{array}$ & Hu et al., 2013 [64] \\
\hline $\begin{array}{l}\text { Language } \\
\text { Signals System }\end{array}$ & $\begin{array}{l}\text { Cognitive development and } \\
\text { 2language comprehension }\end{array}$ & $\begin{array}{l}\text { Acceptable approximations of ASL gestures, which } \\
\text { use combinations of hand gestures to represent a } \\
\text { phrase, word, letter, number, or a combination of } \\
\text { these }\end{array}$ & Brady et al., 2013 [37] \\
\hline $\begin{array}{l}\text { Web-based } \\
\text { survey (joystick) }\end{array}$ & $\begin{array}{l}\text { Facilitate socialization and } \\
\text { communication }\end{array}$ & $\begin{array}{l}\text { A joystick is an input device, equipped with a lever } \\
\text { capable of controlling the movement of a cursor on } \\
\text { the screen, and one or more buttons capable of } \\
\text { controlling certain actions when pressed. The joystick } \\
\text { designs were displayed as rotating 3D objects in } \\
\text { video clips. }\end{array}$ & Allsop et al., 2011 [55] \\
\hline COMPIC & $\begin{array}{l}\text { Language development } \\
\text { (symbols domain) }\end{array}$ & $\begin{array}{l}\text { Communication resource consisting of a library of clear } \\
\text { and easy-to-understand drawings, called 'pictograms', } \\
\text { which contain information }\end{array}$ & Foreman \& Crews, 1998 [8] \\
\hline
\end{tabular}


that aims to verify the visual perception of the individual with a focus on speed and precision when the symbols are "distributed or grouped" (arrangement) with identical content. PCS is one on of the most widely used commercial AAC symbol sets proposed by Mayer Johnson [52].

Grouping symbols and maintaining their original colour increased the speed for target location (food, clothing, activities) in all the participants, including those with DS and those exhibiting typical development, and precision in children with DS [51]. In the construction of a display design, it is essential to consider visual and perceptual characteristics, especially in individuals with DS [53].

\section{COMPIC: Computer-generated pictographs}

One study [8] used computer-generated pictographs (COMPIC) with a total of 19 children with DS from 2 to 4 years old. This study focused on the domain symbols to help identify objects, increase social interaction and language development, and improve their understanding and communication.

In a case study with a 4-year-old child with multiple disabilities, specific COMPIC symbols of his leisure activities (toy cars, blocks, bubbles) were made available. Decision-making and communication development were improved. In addition, an increase in the will to communicate was noted [54].

\section{Web-based survey (joystick)}

One study [55] used a web-based survey (Joystick), with 1 child with DS that was 9 years and 8 months old. It explored a means of retrieving general preferences from children regarding rehabilitation joysticks. The most effective method for designers to use such information remains a challenge (e.g., children's responses outlining a favourite colour were often different to the colour of their preferred joystick design, so it is unclear how a designer should incorporate this potentially conflicting information).

In addition to children with DS, the joystick has also been used with other populations, such as adults suffering from strokes, resulting in improved functional and cognitive abilities [56].

\section{Modified ride-on car}

One study [57] used a modified ride-on car with 1 child with DS who was 1 year and 1 month old. The method resulted in improved communication and socialization. As noted with any single-subject research design, especially one involving an infant, it is difficult to conclude that changes were a result of the intervention and not simply the subject's maturation. It is important to remember that outcome changes are likely due to multiple factors, and this study does not meet every criterion of the single-case study research design [57].
A study involving 6 children from 23 to 38 months old with various cognitive and motor deficits revealed that the subjects presented independent mobility and selfinitiated interactions with educators and everyday objects [58].

\section{Picture-based strategy}

One study [59] used a picture-based strategy with 1 child with DS who was 7 years and 8 months old. The study established the performance of requests, including multiple opportunities for requesting behaviours in a reinforcing context, environmental arrangement to encourage spontaneous communicative attempts, and the use of prompting and modelling to establish the use of effective forms. This study demonstrates that children with DS can benefit from interventions that use images to facilitate the execution of requests [60].

\section{Core vocabulary}

One study [61] with a total of 30 children with DS from 2 to 7 years old used core vocabulary. The core vocabularies of children in the current study serve several syntactic, semantic, and pragmatic functions. Core vocabulary words contained demonstratives (that, these), verbs (to be, to want), pronouns (my), prepositions (on), and articles (the). Without any known focus on teaching core vocabulary within speech-language therapy, these core words seem to emerge in the spontaneous interactions of the children with DS in the current study either in spoken or signed modalities. This result may not occur in other children with complex communication needs who rely on significant others to add core vocabulary to their AAC devices.

An investigated instrument based on the spoken and signed modalities involving children with typical development $[62,63]$ had similar results for children with DS.

\section{Input techniques}

One study [64] with a total of 8 people with DS from 10 to 28 years old used input techniques. Computer devices (keyboard, mouse, speech device, and word prediction software) were used for vocabulary analysis, performance measurement (speed and error rate), and assessment of the child's interaction with the computer [64]. These types of instruments require further analysis given that only a few individuals with DS have the skills/ability to enter a text at a productive speed and with acceptable accuracy. Most people with DS are very slow to enter data, and the generated text typically contains a substantial number of errors.

Children with other disabilities used different devices and showed benefits. Inputs (video cameras, head trackers, and gloves) and outputs (monitors and polarized glasses) 
attached to computers were also used in deaf children [65]. The focus was on cognitive development, resulting in improved visual and tactile perception. In addition, tetraplegic individuals and patients with neurodegenerative diseases, such as amyotrophic lateral sclerosis, also benefit from emulating the mouse to provide mechanical movements and transform them into electrical signals transmitted via a brain-computer interface [66].

\section{Language signals system}

One study [37] used a language signals system. The study included a total of 15 children with DS from 3 to 5 years old. Positive results were demonstrated with the use of sign language (American Sign Language) to assist with cognitive processes, social interaction, and language development (production of different words) [37]. Harris et al. [67] demonstrated that the use of signs significantly increased communication capacity during the development of children with DS and suggested that early association of signals and active communication by the child may have long-term benefits for development.

\section{Digital interactive board}

One study [68] with a total of 9 people with DS from 9 to 29 years old used a digital interactive board. The study demonstrated significant benefits in terms of socialization, autonomy, and consequently individual self-esteem. González et al. [68] used the Divermates prototype to solve a mathematical task. The results showed that touching the screen improves error correction compared with handwriting, which is especially helpful to individuals with DS given their motor difficulties. In addition to the motivational factor in using computer technology, educational tools with attractive designs enable adaptation according to language needs, colour, font size, organization, grouping, categorization of items, and navigation control. González et al. [69] explain that a customized education system has been created with characteristics that are useful to students with special needs, such as DS. This system assists cognitive and motor skills, playing a key role in the learning process.

\section{Study limitations}

This review employed search terms that exhaustively covered all relevant publications. The review also used structured data extraction and quality appraisal to add to the systematic reviewing methods. Nonetheless, limitations in this review must be acknowledged. For some of the identified studies, weak methodologies and few studies using some presented instruments limited the interpretations and conclusions. We believe that these limitations may be attributed to the fact that research in this area and with this population is still considered recent. The most common design flaws were a) the small number of participants and interventions, b) the lack of a control group, and c) the heterogeneity of the sample. Future research should focus on the gaps that these limitations potentially created in studies with this population. Analysis of the methodological quality of the studies using the PEDro scale reveals that many studies failed to perform randomization and simple blinding, which could make the results more consistent. Moreover, we did not identify studies that were rated as 'good' or 'excellent', which can be considered a limitation given that most of the included studies were rated as 'poor' (3) or 'fair' (10).

\section{Applicability}

Devices that help individuals with intellectual and developmental disabilities in schools, associations, or at home daily are important. A lack of support and insufficient training are factors related to the abandonment or limited use of a communication system [70]. Parents, care givers, and the professionals involved must have knowledge about the instrument being used, so they can assist and participate directly in the cognitive and motor development of the individual. Van der Meer et al. [35] noted the importance of taking into account the individual's preference for different choices of AAC as this factor may influence the communication skills and the acquisition tasks. Foreman and Crews [8] suggest the possibility of combining various methods of communication to enable better development.

\section{Future perspectives}

Follow-up studies and better designed methods are needed so we can follow individuals with DS throughout their development. Furthermore, testing the applicability of various AAC devices is necessary to possibly measure effective perspectives that contribute to communication, socialization, language, and motor control.

\section{Conclusion}

Twelve instruments that significantly aided in the communication and socialization of children with DS were identified from this review. This study highlights that these instruments provide significant results for children with DS not only in terms of their interaction with each other but also their interactions with other people who coexist with this population, thereby improving interpersonal relationships. However, some key factors should be considered in using such technological devices, including preferences, professional and parent training, joint use of the devices, display design, and above all stratification of the cognitive level before any intervention. Future investigations in communication and socialization of children with DS should employ standardized methods. 


\section{Additional files}

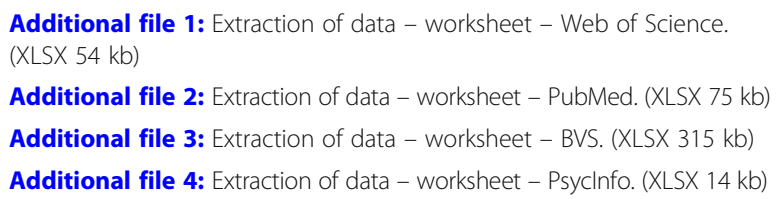

Additional file 1: Extraction of data - worksheet - Web of Science. (XLSX $54 \mathrm{~kb}$ )

Additional file 2: Extraction of data - worksheet - PubMed. (XLSX 75 kb)

Additional file 3: Extraction of data - worksheet - BVS. (XLSX $315 \mathrm{~kb}$ )

Additional file 4: Extraction of data - worksheet - Psyclnfo. (XLSX 14 kb)

\section{Abbreviations}

AAC: Augmentative and Alternative Communication; ALS: American Sign Language; ASD: Autism Spectrum Disorder; COMPIC: Computer-Generated Pictographs; CP: Cerebral Palsy; DD: Developmental Disability; DS: Down's Syndrome; F: Female; ISF: Intrinsic Symbolic Factor; M: Male; MAKATON: Sign Language System; MSSD: Multisystem Developmental Disorder; PCS: Picture Communication Symbols; PECS: Picture Exchange Communication System; PEDI: Pediatric Evaluation of Disability Inventory; ROCs: Modified Ride-on Cars; SA: Support Assistants; SD: Standard Deviation; SGDs: Speech-Generating Devices; TD: Typical Development

\section{Acknowledgements}

The authors would like to thank CAPES (Higher Education Personnel Training Coordination). Call Notice No. 59/2014 - PGPTA and the UNIEDU-SC postgraduate programme.

\section{Availability of data and materials}

The data sets supporting the conclusions of this article are included within the article (Additional file 1, Additional file 2, Additional file 3, and Additional file 4).

\section{Authors' contributions}

RTAB structured the script and directed the work; RTAB and JYFLA collected the studies and organized the data; TM, TBC and CA structured the method and study analysis; ASBO, CBMM and LCA structured the introduction, discussion, and conclusion; CA and TPCA adapted the work to the English language; RG, TPCA and IMPB helped in the construction of the discussion; and LCA reviewed and generally organized the manuscript. All authors have read and approved the manuscript.

\section{Ethics approval and consent to participate}

Not applicable

\section{Competing interests}

The authors declare that they have no competing interests.

\section{Publisher's Note}

Springer Nature remains neutral with regard to jurisdictional claims in published maps and institutional affiliations.

\section{Author details}

'Laboratório de Delineamento de Estudos e Escrita Científica, Departamento de Saúde da Coletividade, Faculdade de Medicina do ABC (FMABC), Rua Fagundes Varela, 121. Vila Príncipe de Gales, 09060510 Santo André, SP, Brasil. ${ }^{2}$ Escola Paulista de Medicina, Disciplina de Neurologia Clínica. Setor de Doenças Neuromusculares, Universidade Federal de São Paulo (UNIFESP-EPM), Rua Botucatu, 740, Vila Mariana, 04023900 São Paulo, SP, Brasil. ${ }^{3}$ Escola Paulista de Medicina. Disciplina de Cardiologia, Departamento de Medicina, Universidade Federal de São Paulo (UNIFESP), Rua Napoleão de Barros, 715, Vila Clementino, 04023062 São Paulo, SP, Brasil. ${ }^{4}$ Programa de Pós-Graduação em Ciências da Reabilitação, Faculdade de Medicina, Universidade de São Paulo (USP), Rua Cipotânea, 51, Cidade Universitária, 05360000 São Paulo, SP, Brasil. ${ }^{5}$ Escola Superior de Ciências da Santa de Misericórdia de Vitória (EMESCAM), Av. N.S da Penha, 2190, Santa Luiza, 29045402 Vitória, ES, Brasil. ${ }^{6}$ Escola de Artes, Ciências e Humanidades, Universidade de São Paulo (EACH-USP), Rua Arlindo Béttio, 1000, Ermelino Matarazzo, 03828000 São Paulo, SP, Brasil. DDepartamento de Saúde Materno Infantil, Faculdade de Saúde Pública, Universidade de São Paulo (USP), Av. Dr. Arnaldo, 715, 01246904 São Paulo, SP, Brasil.
Received: 10 January 2017 Accepted: 3 May 2018

Published online: 11 May 2018

\section{References}

1. Genes and human disease [http://www.who.int/genomics/public/ geneticdiseases/en/index1.html]. Accessed 5 May 2017.

2. Oster-Granite ML, Parisi MA, Abbeduto L, Berlin DS, Bodine C, Bynum D, Capone G, Collier E, Hall D, Kaeser L, et al. Down syndrome: national conference on patient registries, research databases, and biobanks. In: Mo Genet Metab. United States: Copyright (c). Published by Elsevier Inc. All rights reserved. 2011;104(1-2):13-22. https://doi.org/10.1016/j.ymgme.2011. 07.005 .

3. Arumugam A, Raja K, Venugopalan M, Chandrasekaran B, Kovanur Sampath K, Muthusamy $H$, Shanmugam N. Down syndrome-a narrative review with a focus on anatomical features. Clin Anat. 2016;29(5):568-77. https://doi.org/ 10.1002/ca.22672.

4. Kim HI, Kim SW, Kim J, Jeon HR, Jung DW. Motor and cognitive developmental profiles in children with Down syndrome. Ann Rehabil Med. 2017;41(1):97-103. https://doi.org/10.5535/arm.2017.41.1.97.

5. Lana-Elola E, Watson-Scales SD, Fisher EM, Tybulewicz VL. Down syndrome: searching for the genetic culprits. Dis Model Mech. 2011;4(5):586-95. https://doi.org/10.1242/dmm.008078.

6. Silverman W. Down syndrome: cognitive phenotype. Ment Retard Dev Disabil Res Rev. 2007;13(3):228-36. https://doi.org/10.1002/mrdd.20156.

7. Latash ML. Learning motor synergies by persons with Down syndrome. J Intellect Disabil Res. 2007;51(Pt 12):962-71. https://doi.org/10.1111/j.13652788.2007.01008.x

8. Foreman P, Crews G. Using augmentative communication with infants and young children with Down syndrome. Downs Syndr Res Pract. 1998;5(1):16-25. https://doi.org/10.3104/reports.71.

9. Rodenbusch TL, Ribeiro TS, Simao CR, Britto HM, Tudella E, Lindquist AR. Effects of treadmill inclination on the gait of children with Down syndrome. Res Dev Disabil. 2013;34(7):2185-90. https://doi.org/10.1016/j.ridd.2013.02.014.

10. Bez MR, Passerino LM. Scala 2.0:alternative comunicação software for web. In: Revista Avances Investigación en Ingeniería, vol. 9; 2012. p. 120-7.

11. Pullin G, Treviranus J, Patel R, Higginbotham J. Designing interaction, voice, and inclusion in AAC research. Augment Altern Commun. 2017:33(3):13948. https://doi.org/10.1080/07434618.2017.1342690.

12. Baxter $S$, Enderby $P$, Evans $P$, Judge S. Interventions using high-technology communication devices: a state of the art review. Folia Phoniatr Logop. 2012;64(3):137-44. https://doi.org/10.1159/000338250.

13. Soto G, Clarke MT. Effects of a conversation-based intervention on the linguistic skills of children with motor speech disorders who use augmentative and alternative communication. J Speech Lang Hear Res. 2017;60(7):1980-98. https://doi.org/10.1044/2016_JSLHR-L-15-0246.

14. Finke EH, Davis JM, Benedict M, Goga L, Kelly J, Palumbo L, Peart T, Waters S. Effects of a least-to-most prompting procedure on multisymbol message production in children with autism Spectrum disorder who use augmentative and alternative communication. Am J Speech Lang Pathol. 2017;26(1):81-98. https://doi.org/10.1044/2016_AJSLP-14-0187.

15. Russo MJ, Prodan V, Meda NN, Carcavallo L, Muracioli A, Sabe L, Bonamico $\mathrm{L}$, Allegri RF, Olmos L. High-technology augmentative communication for adults with post-stroke aphasia: a systematic review. Expert Rev Med Devices. 2017;14(5):355-70. https://doi.org/10.1080/17434440.2017.1324291.

16. Næss K-AB, Melby-Lervåg M, Hulme C, Lyster S-AH. Reading skills in children with Down syndrome: a meta-analytic review. Res Dev Disabil. 2012;33(2): 737-47. https://doi.org/10.1016/j.ridd.2011.09.019.

17. Næss K-AB, Lyster S-AH, Hulme C, Melby-Lervåg M. Language and verbal short-term memory skills in children with Down syndrome: a meta-analytic review. Res Dev Disabil. 2011;32(6):2225-34. https://doi.org/10.1016/j.ridd. 2011.05.014

18. Grieco J, Pulsifer M, Seligsohn K, Skotko B, Schwartz A. Down syndrome: cognitive and behavioral functioning across the lifespan. In: American journal of medical genetics part C: seminars in medical genetics: Wiley Online Library. 2015;169(2):135-49. https://doi.org/10.1002/ajmg.c.31439.

19. Ricketts J. Research review: reading comprehension in developmental disorders of language and communication. J Child Psychol Psychiatry. 2011; 52(11):1111-23. https://doi.org/10.1111/j.1469-7610.2011.02438.x.

20. Hutton B, Salanti G, Caldwell DM, Chaimani A, Schmid CH, Cameron C, loannidis JP, Straus S, Thorlund K, Jansen JP, et al. The PRISMA extension statement for reporting of systematic reviews incorporating network meta- 
analyses of health care interventions: checklist and explanations. Ann Intern Med. 2015;162(11):777-84. https://doi.org/10.7326/M14-2385.

21. Knobloch $K$, Yoon U, Vogt P. Preferred reporting items for systematic reviews and meta-analyses (PRISMA) statement and publication bias. $J$ Cranio-Maxillofac Surg. 2011;39(2):91-2. https://doi.org/10.1016/j.jcms.2010. 11.001.

22. Panic N, Leoncini E, de Belvis G, Ricciardi W, Boccia S. Evaluation of the endorsement of the preferred reporting items for systematic reviews and meta-analysis (PRISMA) statement on the quality of published systematic review and meta-analyses. PLoS One. 2013;8(12):e83138. https://doi.org/10. 1371/journal.pone.0083138.

23. Massetti T, Trevizan IL, Arab C, Favero FM, Ribeiro-Papa DC, de Mello Monteiro CB. Virtual reality in multiple sclerosis - a systematic review. Mult Scler Relat Disord. 2016;8:107-12. https://doi.org/10.1016/j.msard.2016.05. 014.

24. Sampaio RF, Mancini MC: Estudos de revisão sistemática: um guia para síntese criteriosa da evidência científica. Brazilian Journal of Physical Therapy. 2007;11(1):83-89. https://dx.doi.org/10.1590/S141335552007000100013

25. Massetti T, Crocetta TB, Silva TDD, Trevizan IL, Arab C, Caromano FA, Monteiro CBM. Application and outcomes of therapy combining transcranial direct current stimulation and virtual reality: a systematic review. Disabil Rehabil Assist Technol. 2017;12(6):551-9. https://doi.org/10.1080/ 17483107.2016.1230152.

26. Massetti T, TDd S, Ribeiro DC, SRP M, AHN R, Favero FM, CBdM M. Motor learning through virtual reality in cerebral palsy-a literature review. MedicalExpress. 2014;1 (6):302-6. http://dx.doi.org/10.5935/MedicalExpress. 2014.06.04.

27. De Menezes LDC, Massetti T, Oliveira FR, De Abreu LC, Malheiros SRP, Trevizan IL, Moriyama CH, De Mello Monteiro CB. Motor learning and virtual reality in Down syndrome; a literature review. Int Arch Med. 2015;8:1-11. http://dx.doi.org/10.3823/1718.

28. Digiácomo MJ, IA DIGIÁCOMO. Estatuto da criança e do adolescente anotado e interpretado. Curitiba: Ministério Público do Estado do Paraná; 2010. [http://www.mpdft.mp.br/portal/pdf/unidades/promotorias/pdij/ Legislacao\%20e\%20Jurisprudencia/ECA_comentado.pdf]. Accessed 15 May 2017.

29. Abrantes MM, Lamounier JA, Colosimo EA. Prevalência de sobrepeso e obesidade em crianças e adolescentes das regiões Sudeste e Nordeste. Pediatr. 2002;78(4):335-40. http://dx.doi.org/10.1590/S002175572002000400014

30. Arab C, Dias DPM, de Almeida Barbosa RT, de Carvalho TD, Valenti VE, Crocetta TB, Ferreira M, de Abreu LC, Ferreira C. Heart rate variability measure in breast cancer patients and survivors: a systematic review. Psychoneuroendocrinology. 2016;68:57-68. https://doi.org/10.1016/j. psyneuen.2016.02.018.

31. Beaton D, Bombardier C, Guillemin F, Ferraz MB. Recommendations for the cross-cultural adaptation of the DASH \& QuickDASH outcome measures. Institute for Work \& Health. 2007:1(1):1-45.

32. Verhagen AP, de Vet HC, de Bie RA, Kessels AG, Boers M, Bouter LM, Knipschild PG. The Delphi list: a criteria list for quality assessment of randomized clinical trials for conducting systematic reviews developed by Delphi consensus. J Clin Epidemiol. 1998;51(12):1235-41.

33. Maher CG, Sherrington C, Herbert RD, Moseley AM, Elkins M. Reliability of the PEDro scale for rating quality of randomized controlled trials. Phys Ther. 2003;83(8):713-21.

34. Snider L, Majnemer A, Darsaklis V. Virtual reality as a therapeutic modality for children with cerebral palsy. Dev Neurorehabil. 2010;13(2):120-8. https:// doi.org/10.3109/17518420903357753.

35. Van der Meer L, Kagohara D, Achmadi D, O'Reilly MF, Lancioni GE, Sutherland D, Sigafoos J. Speech-generating devices versus manual signing for children with developmental disabilities. Res Dev Disabil. 2012;33(5): 1658-69. https://doi.org/10.1016/j.ridd.2012.04.004.

36. Barker RM, Akaba S, Brady NC, Thiemann-Bourque K. Support for AAC use in preschool, and growth in language skills, for young children with developmental disabilities. Augment Altern Commun. 2013;29(4):334-46. https://doi.org/10.3109/07434618.2013.848933.

37. Brady NC, Thiemann-Bourque K, Fleming K, Matthews K. Predicting language outcomes for children learning augmentative and alternative communication: child and environmental factors. J Speech Lang Hear Res. 2013;56(5):1595-612. https://doi.org/10.1044/1092-4388(2013/12-0102).
38. Lorah ER. Comparing teacher and student use and preference of two methods of augmentative and alternative communication: picture exchange and a speech-generating device. J Dev Phys Disabil. 2016;28(5): 751-67. https://doi.org/10.1007/s10882-016-9507-z.

39. Sigafoos J, Green VA, Payne D, Son SH, O'Reilly M, Lancioni GE. A comparison of picture exchange and speech-generating devices: acquisition, preference, and effects on social interaction. Augment Altern Commun. 2009;25(2):99-109. https://doi.org/10.1080/07434610902739959.

40. Luke C. Impact of speech-generating devices on the language development of a child with childhood apraxia of speech: a case study. Disabil Rehabil Assist Technol. 2016;11(1):80-8. https://doi.org/10.3109/17483107.2014.913715.

41. Franco JH, Lang RL, O'Reilly MF, Chan JM, Sigafoos J, Rispoli M. Functional analysis and treatment of inappropriate vocalizations using a speech-generating device for a child with autism. Focus on Autism and Other Developmental Disabilities. 2009:24(3):146-55. https://doi.org/10.1177/1088357609338380.

42. Van der Meer LA, Rispoli M. Communication interventions involving speechgenerating devices for children with autism: a review of the literature. Dev Neurorehabil. 2010;13(4):294-306. https://doi.org/10.3109/ 17518421003671494

43. Boesch MC, Wendt O, Subramanian A, Hsu N. Comparative efficacy of the picture exchange communication system (PECS) versus a speech-generating device: effects on social-communicative skills and speech development. Augment Altern Commun. 2013;29(3):197-209. https://doi.org/10.3109/ 07434618.2013 .818059

44. Waddington $\mathrm{H}$, Sigafoos J, Lancioni GE, O'Reilly MF, Van der Meer L, Carnett A, Stevens M, Roche L, Hodis F, Green VA, et al. Three children with autism spectrum disorder learn to perform a three-step communication sequence using an iPad(R)-based speech-generating device. Int J Dev Neurosci. 2014; 39:59-67. https://doi.org/10.1016/j.jidevneu.2014.05.001.

45. Smith J, Hand L, Dowrick PW. Video feedforward for rapid learning of a picture-based communication system. J Autism Dev Disord. 2014:44(4):92636. https://doi.org/10.1007/s10803-013-1946-0.

46. Yoder $\mathrm{P}$, Stone WL. Randomized comparison of two communication interventions for preschoolers with autism spectrum disorders. J Consult Clin Psychol. 2006;74(3):426-35. https://doi.org/10.1037/0022-006X.74.3.426.

47. Yoder $\mathrm{P}$, Stone WL. A randomized comparison of the effect of two prelinguistic communication interventions on the acquisition of spoken communication in preschoolers with ASD. J Speech Lang Hear Res. 2006; 49(4):698-711. https://doi.org/10.1044/1092-4388(2006/051).

48. Anslow K. Systemic family therapy using the reflecting team: the experiences of adults with learning disabilities. Br J Learn Disabil. 2013;42: 236-43. https://doi.org/10.1111/bld.12048.

49. Brownjohn MDR. Acquisition of Makaton Symbols by a young man with severe learning difficulties. Behav Psychother. 1988;16:85-94. https://doi.org/ 10.1017/S0141347300012891.

50. Mistry M, Barnes D. The use of Makaton for supporting talk, through play, for pupils who have English as an additional language (EAL) in the foundation stage. Education 3-13: International Journal of Primary, Elementary and Early Years Education. 2013:41(6):603-16. https://doi.org/10. 1080/03004279.2011.631560

51. Wilkinson $\mathrm{K}$, Carlin M, Thistle J. The role of color cues in facilitating accurate and rapid location of aided symbols by children with and without Down syndrome. Am J Speech Lang Pathol. 2008;17(2):179-93. https://doi.org/10. 1044/1058-0360(2008/018).

52. Wilkinson KM, Mcllvane WJ. Perceptual factors influence visual search for meaningful symbols in individuals with intellectual disabilities and Down syndrome or autism spectrum disorders. Am J Intellect Dev Disabil. 2013; 118(5):353-64. https://doi.org/10.1352/1944-7558-118.5.353.

53. Wilkinson KM, Carlin M, Jagaroo V. Preschoolers' speed of locating a target symbol under different color conditions. Augment Altern Commun. 2006: 22(2):123-33. https://doi.org/10.1080/07434610500483620.

54. Chan JB, May DT. The impact of leisure options on the frequency and spontaneous communication production of a young child with multiple disabilities. Br J Dev Disabil. 1999;45(88):26-37. https://doi.org/10.1179/ 096979599799156000.

55. Allsop M, Gallagher J, Holt R, Bhakta B, Wilkie R. Involving children in the development of assistive technology devices. Disabil Rehabil Assist Technol. 2011:6(2):148-56. https://doi.org/10.3109/17483107.2010.510178.

56. Reinkensmeyer DJ, Pang CT, Nessler JA, Painter CC. Web-based telerehabilitation for the upper extremity after stroke. IEEE Trans Neural Syst Rehabil Eng. 2002;10(2):102-8. https://doi.org/10.1109/TNSRE.2002.1031978. 
57. Logan SW, Huang H-H, Stahlin K, Galloway JC. Modified ride-on car for mobility and socialization: single-case study of an infant with Down syndrome. Pediatr Phys Ther. 2014;26(4):418-26. https://doi.org/10.1097/PEP. 0000000000000070.

58. Butler $\mathrm{C}$. Effects of powered mobility on self-initiated behaviors of very young children with locomotor disability. Dev Med Child Neurol. 1986; 28(3):325-32.

59. Lanter E, Russell SD, Kuriakose A, Blevins KE. Incorporating AAC and general instructional strategies in requesting interventions: a case study in Down syndrome. Commun Disord Q. 2016;38(1):52-63. https://doi.org/10.1177/ 1525740115602093.

60. Kern L, Gallagher P, Starosta K, Hickman W, George M. Longitudinal outcomes of functional behavioral assessment-based intervention. J Posit Behav Interv. 2006;8(2):67-78.

61. Deckers SR, Van Zaalen Y, Van Balkom H, Verhoeven L. Core vocabulary of young children with Down syndrome. Augment Altern Commun. 2017; 33(2):77-86. https://doi.org/10.1080/07434618.2017.1293730.

62. Banajee M, Dicarlo C, Buras Stricklin S. Core vocabulary determination for toddlers. Augment Altern Commun. 2003;19(2):67-73. https://doi.org/10. 1080/0743461031000112034.

63. Trembath D, Balandin S, Togher L. Vocabulary selection for Australian children who use augmentative and alternative communication. J Intellect Dev Disabil. 2007;32(4):291-301. https://doi.org/10.1080/ 13668250701689298

64. Hu R, Feng J, Lazar J, Kumin L. Investigating input technologies for children and young adults with Down syndrome. Univ Access Inf Soc. 2013;12(1):89104. https://doi.org/10.1007/s10209-011-0267-3.

65. Dainese C, Garbin T, Kirner C. Sistema de Realidade Aumentada para Desenvolvimento Cognitivo da Criança Surda. In: Anais do 6th SBC symposium on virtual reality, Ribeirão Preto, Brasil; 2003. p. 273-82.

66. Müller AF, Zaro MA, Jr DPS, Sanches PRS, Ferlin EL, Thomé PRO. Dispositivo para emulação de mouse dedicado a pacientes tetraplégicos ou portadores de doença degenerativa do sistema neuromuscular. Acta Fisiátrica. 2001;8(2):63-6.

67. Harris S, Kasari C, Sigman MD. Joint attention and language gains in children with Down syndrome. Am J Ment Retard. 1996;100(6):608-19.

68. González C, Noda A, Bruno A, Moreno L, Muñoz V. Learning subtraction and addition through digital boards: a Down syndrome case. Univ Access Inf Soc. 2015;14:29-44. https://doi.org/10.1007/s10209-013-0330-3.

69. González C, Guerra D, Sanabria H, Moreno L, Noda M, Bruno A. Automatic system for the detection and analysis of errors to support the personalized feedback. Expert Systems with Applications. 2010;37(1):140-8. https://doi. org/10.1016/j.eswa.2009.05.027.

70. Johnson JM, Inglebret E, Jones C, Ray J. Perspectives of speech language pathologists regarding success versus abandonment of AAC. Augment Altern Commun. 2006;22(2):85-99. https://doi.org/10.1080/ 07434610500483588

Ready to submit your research? Choose BMC and benefit from:

- fast, convenient online submission

- thorough peer review by experienced researchers in your field

- rapid publication on acceptance

- support for research data, including large and complex data types

- gold Open Access which fosters wider collaboration and increased citations

- maximum visibility for your research: over $100 \mathrm{M}$ website views per year

At BMC, research is always in progress.

Learn more biomedcentral.com/submissions 